\title{
Le Bailli Pierre-André de Suffren: A Precursor of Nelson
}

\author{
Rémi Monaque \\ Marine française
}

There was nothing about the young Suffren, when he joined the company of Gardes Marine in Toulon at the age of 14 in October 1743, that would have marked him out to become an innovator in naval tactics and strategy. $\mathrm{He}$ belonged to the high nobility of Provence, which provided at this time a quarter of the officers of the royal navy, and he followed the usual training for future senior officers of the navy, receiving the classic instruction in the doctrine that prevailed at the time. However, very soon, an event ocurred that was favourable to his training; after a 30-year interval, hostilities between France and Great Britain broke out again. In January 1744, Pierre-André left the classrooms of the arsenal in Toulon to embark on the Solide (64) and only a few weeks later participated in the Battle of Toulon (22 February 1744 n.s.), during which the French squadron commanded by Court de La Bruyère, a 78-year-old admiral, made it possible for a Spanish squadron which had been sheltering in Toulon to break out of the port and head back to Cádiz in spite of the opposition of the British Admiral Mathews' blockading squadron.

Except for six months on land with the naval guards at Brest, Suffren remained on board throughout the war, undergoing a thorough training à l'anglaise' (at

How to cite this book chapter:

Monaque, R. 2017. Le Bailli Pierre-André de Suffren: A Precursor of Nelson. In: Harding, R and Guimerá, A (eds.). Naval Leadership in the Atlantic World. Pp. 85-91. London: University of Westminster Press. DOI: https://doi. org/10.16997/book2.h. License: CC-BY-NC-ND 4.0 
sea) with many enriching experiences. The last of them is his service on the Monarque (74), which, on 25 October 1747, took part in a heroic combat off the coast of Ouessant (the Second Battle of Cape Finisterre). In this battle, the eight vessels of the chef d'escadre, Des Herbiers de l'Etenduère, charged with protecting a huge convoy of ships towards the West Indies, were attacked by Rear Admiral Edward Hawke's 14 vessels. The French admiral succeeded in saving the convoy at the price of a seven-hour battle during which six French vessels were captured after they had defended themselves heroically. Suffren, taken prisoner on the Monarque, had his first experience of captivity and especially the terrible humiliation of witnessing the victory of Hawke who sailed triumphantly up the Thames with the spoils of war. This cruel experience left a mark on him that lasted all his life and maintained his unrelenting hatred of the English.

Suffren took advantage of the short period between 1748 and 1756 that separated the War of the Austrian Succession from the Seven Years' War to go to Malta to be trained as a Knight of Saint John of Jerusalem. During the whole of his adult life, Suffren performed, alternatively, his services in Malta and in the King's navy. Taking both careers hand in hand, he cleverly leaned on each of them to ensure progress in both. Was Suffren's style of commanding influenced by this double affiliation? Yes, certainly, but not so much in the domain of naval operations, because by this time the heroic conflicts of the Christian states with Turks and the inhabitants of the Barbary Coast were over. However, there remained in this history a glorious tradition of attacking the enemy with energy, and a spirit of sacrifice without taking into account the risks. Much more surely, the admiral developed, during his sojourns in Malta, a constant interest in the physical and moral health of his crew members. In his role of a good Knight Hospitaller monk, he showed great solicitude for the sick and the wounded, and knew how to take concrete measures to improve the daily life of his crew. Ultimately, he owed his fame largely to this attitude.

The Seven Years' War (1756-63) brought Suffren new and enriching experiences. In 1756, he participated in the French victory at Minorque (20 May 1756), won by the chef descadre, the Marquis de La Gallisonnière, over the unfortunate Rear Admiral John Byng, who, for his failure to do his utmost in this battle, was judged by court martial, condemned to death and executed on 14 March $1757 .{ }^{186}$ Nicholas Rodger believes that this general officer, who did not deserve such a punishment, was the victim of 'the king's anger, the fury of public opinion and the disgust of his naval colleagues. On this occasion, Pierre-André was able to note the fact that combat on parallel lines is ineffectual when the adversary (in this case the English), lying windward, is satisfied with a cannonade at long distance without forcing his adversary to close combat. The Battle of Lagos, in August 1759, was far more dramatic. Suffren, now a lieutenant, was aboard the Ocean, the flagship of Admiral M. de la Clue. The admiral, after an opening battle when his squadron was dispersed, had taken 
refuge with four of his vessels in Portuguese, and therefore neutral, waters in Lagos Bay. He was pursued by Admiral Edward Boscawen who, with contempt for international law, burned two of the vessels, which had surrendered, and captured the other two. Pierre-André was imprisoned once again. Some 20 years later, he was still able to remember this cynical lesson in realism and he did not hesitate, in his turn, to infringe Portuguese neutrality at the Battle of Porto Praya (16 April 1781).

During the long truce which separated the Seven Years' War in 1763 from the outbreak of the American War of Independence in 1775, Pierre-Andrés reputation began to grow both in the King's navy and that of Malta. He was given many commands: two xebecs, two frigates and a Maltese galley. During these years between the wars, Pierre-André, as a captain, participated in the campaigns of training squadrons where he was able to perfect his manoeuvring and tactical art. When war was declared on Britain in 1778, he was appointed to the command of the Fantasque (64).

During the American War of Independence, Suffren served at sea from the first day to the last. In command of the Fantasque, he was part of the first squadron sent to aid the American rebels under the orders of d'Estaing. This unusual admiral was from a family of the highest nobility. He had come from the army and had entered the navy with a high rank of flag officer. This undeserved promotion, like his maritime incompetence, engendered the hostility of almost all the naval officers. However, he did not lack other great qualities such as courage, tenacity and a remarkable capacity to discern the talents of his subordinates. It did not take d'Estaing long to understand that Suffren, who had a relatively low rank in the naval hierarchy, was his best captain. D'Estaing put him in charge of the most delicate missions, giving him the authority to command bigger and bigger forces. Pierre-André took advantage of these opportunities to improve his skills in managing the tactical formation of squadrons and did not hesitate, sometimes with scant ceremony, to criticise the way in which the squadron was being commanded. He distinguished himself on a number of occasions, notably at Newport by compelling five English frigates to scuttle (29 July 1778) and at the Battle of La Grenade (15 December 1778) where he took the first place in the French line, dauntlessly coming under the enemy fire of the whole English squadron.

During this campaign, when many opportunities were lost by the French, Suffren sharpened his strategic and tactical conceptions and, little by little, reached the conclusion that one can obtain definite success on only two conditions: engage in very close combat with the enemy and concentrate the greatest section of one's own fighting force on a section of the enemy squadron.

This conviction was a result not only of his own vast experience but also of his historical readings, and especially a study of the campaigns of the great Dutch Admiral Michiel de Ruyter (1607-76) for whom he felt profound admiration. From de Ruyter and his own experiences Pierre-André understood that 
close combat is fairly simple, at least if you have the advantage of a favourable wind, and so the possibility of getting as close as possible to one's adversary was the key to victory. Great courage and authority are all one needs: great courage to place one's vessel in an extremely dangerous position where it will receive at point-blank range the gunfire of the enemy; great authority to persuade the captains to do the same. It is much more difficult to arrive at a concentration of forces. For Pierre-André this implied renouncing fighting in one continuous line and spreading out one's squadron in several autonomous divisions capable of individual, particular manoeuvres, while still respecting the principle of strict coordination. The Commander must therefore have captains capable of taking initiatives, well-informed of the manoeuvres that are envisaged and of the intentions of the admiral. These conditions would later be realised admirably in the hearts of the famous Band of Brothers that served under Nelson. Alas, Suffren was never able to obtain a similar cohesion of minds and hearts among his officers.

After his command of the Fantasque, Pierre-André was put in charge of a more powerful vessel, the Zélé (74). He distinguished himself in this warship by taking part in the capture of a huge British convoy off the Portuguese coasts (9 August 1780). It was only in March 1781 that he at last received a command worthy of his talents. A little squadron of five vessels, armed at Brest, was put in his charge with the mission of protecting the Dutch colony at the Cape, then under threat of an English attack; then to sail on to Mauritius and join the Indian Ocean squadron commanded by M. d'Orves. This rather mediocre admiral had the good idea of dying in February 1782, leaving the command to Suffren for his famous campaign of the Indies where the bailli finished up having 15 vessels and holding on for two years against the English squadron under Admiral Hughes. Of this famous campaign, I will mention only two examples which illustrate marvellously the type of leadership practised by Suffren.

It was at Porto La Praya, in the Portuguese isles of Cape Verde, on 16 April 1781 , in the extraordinary battle against Commodore Johnstone, that the possession of the Cape of Good Hope was settled. The British officer who had been ordered to capture this colony had left Europe a few days before Suffren. The latter, who had no information about the position of his adversary, decided to make a stop at this neutral country in order to complete his provisions and to refresh the crew members. On approaching La Praya, the leading French ship noticed spars in the harbour, turned around and informed his commander. In a flash, Pierre-André made a decision. He placed the Héros (74) at the head of the line, ordered the other ships to get closer to one another and clear the ships for action while making a rush at the enemy. The English, lacking vigilance, were confined without order at the bottom of the bay; warships and transport vessels all mixed together. They were completely surprised. The Héros, followed by the Annibal (74), penetrated into the harbour, firing from both sides, and placed itself in a broadside position at a short distance from an enemy vessel. 
The Annibal did the same and placed itself in front of its leader. But her guns remained practically silent.

Captain Trémigon, who commanded the Annibal, thought there would be no fighting in neutral waters, and neglected to make his preparations for action. Seriously wounded from the beginning of the action, this unforgivable omission cost him his life. The third vessel of the line, the Artésien (64), succeeded in penetrating the heart of the enemy formation, but its commanding officer, the Chevalier de Cardaillac, was killed at the moment he ordered the anchoring of his ship. The order was not executed and the vessel, pushed on by wind and currents, sailed out of the harbour. The last two vessels were also forced out without being able to participate effectively in the combat. Thus Suffren found himself in the middle of a furnace with just two ships, only one of which was fit for battle. Overwhelmed by attacks from all sides, the only solution he had was to cut all the cables in order to get out of a deadly trap. The Annibal, soon totally dismasted, imitated the manoeuvre of its commander and the two vessels, helped by favourable wind and current, managed to extricate themselves and leave the harbour. With remarkable energy and sangfroid, Suffren gathered his forces together and formed a tight line with his five ships, ordering the Sphinx to tow the dismasted Annibal. Now it was a matter of confronting on the high seas the English squadron that had got over its surprise and sailed out. But Johnstone hesitated to attack an adversary who seemed extremely capable and the pursuit of whom would take him far under the winds of Praya, where he had left some of his men and a convoy in great disorder. After a chase of six days, the British commander gave up all hope of combat and sailed back to the port. He had lost the race to the Cape and was not able to accomplish his mission. Suffren had led an extraordinary action, had not been understood by his captains and had suffered heavy losses without inflicting similar losses on his enemy. Even so, his audacity and ability to make decisions had paid off. Johnstone was definitely distanced and the Cape, where the Frenchman was able to land a strong garrison force, was saved.

The Battle of Sadras (17 February 1782) will be my second example. Suffren, now at the head of 12 vessels - his squadron had been strengthened by six vessels lying at the Île-de-France and the capture of an English vessel - had arrived at the Coast of Coromandel. He knew that his adversary, Vice-Admiral Sir Edward Hughes, still had only nine ships of the line. He decided to get rid of Hughes as soon as possible. The meeting took place on 17 February 1782 off the coast of Sadras. Suffren had prepared for the battle with particular care, with the idea of a completely new technique. Instead of being content, as was the usual practice at the time, with sailing along the whole line of enemy vessels and doubling his rear guard with the three extra vessels, the 'bailli' (Dignitary of the Order of Malta) intended not to attack the three leading British vessels and, instead, overcome the following six by placing them between two lines of six French vessels. He himself, on board the Héros, the leading vessel, took good care to prevent the 
three English vessels that were not being attacked, from tacking to come to the aid of their fellows. He had taken the trouble of explaining this manoeuvre in writing to Tromelin, the senior captain, asking him to take the initiative, when the time came, to assure the surrounding of the enemy line from behind. Alas, this brilliant idea, which would have permitted the concentration of the French forces on six enemy vessels, was not understood by the majority of the captains and was even sabotaged by Tromelin, who just repeated the signals of the commander without executing them. Only two French vessels doubled the English line - the manoeuvre however permitted the crippling of the British ships Superb and Exeter which were almost captured. Hughes was able to escape without losing ships but had to sail to Trincomalee to repair the badly damaged vessels. The area was left free for Suffren to land the French troops in Portonovo, not far from Pondicherry, in a zone controlled by their ally, the Nawab Heider Ali.

The two examples mentioned obviously show the lack of communication between Suffren and his captains. Having an inflexible, ironic and abrupt character, he did not make any real effort to be understood by his subordinates. $\mathrm{He}$ even took a malicious pleasure in shocking them by wearing slovenly-looking clothes and using a language littered with Provençal swear-words, more frequently heard on the lower deck than on the quarter-deck. Pierre-Andrés orders, as soon as they diverged from routine, were badly understood and therefore badly executed. It is true that there were, under his orders, many captains whose professional level was mediocre and, even worse, who were very badly disposed towards him. So difficult was his character that he managed to discourage even those who had the best intentions. What is more, even when his tactical inspiration was brilliant, Suffren did not conduct the action with all the necessary rigour and precision. His ardour and impatience made him multiply orders and counter-orders, and flag signals, which were not always very clear. So there often followed a lot of confusion in the execution of the manoeuvres he had set in motion.

In short, Suffren as a tactician is disappointing. His accomplishments fell short of his original ideas. He totally lacked a pedagogical sense and disliked gathering together his captains to explain his ideas of manoeuvring, to obtain comprehension and their commitment. He had no notion of the training that is indispensable if one wants to get out of routine and achieve the unusual. On the other hand, his ardour, his tenacity and his aggressive behaviour had wonderful results and he ended up winning the respect of his captains and the sincere admiration of his adversaries. On 20 June 1783, in the course of his last battle, at Cuddalore, fighting with 15 vessels against 18, he manifested his superiority over Hughes, who was forced to give up his attempts to give aid to the attacking British army and retired to Calcutta. One circumstance, perhaps unique in naval history, crowns Pierre-Andrés glorious career. On 22 December 1783, the Héros, Suffren's flagship, arrived at Table Bay in the Dutch Cape Colony, where Commodore Sir Richard King's English squadron lay at anchor. The 
British historian and Admiral, Ballard, related that a host of British officers went aboard the Héros 'to greet personally a master of their profession'. Suffren deserves to be ranked among the very great seamen, between Ruyter and Nelson, whose destructive injunction to 'annihilate the enemy' he could well have made his own. But his intuitions, his courage and his obstinacy brought him only limited success, as his action was so cramped by negative characteristics which prevented him from assembling all the forces around himself. 
